\title{
Comparative Analysis on Privatization (Restitution \& Compensation) Process of Property between Albania versus Southeastern, Eastern and Central European Countries as Romania, Poland and the Czech Republic

\author{
PhD Candidate Elona Krashi
}

\author{
Faculty of Social Sciences, University of Tirana \\ ekrashi@gmail.com
}

\section{PhD Candidate Ermelinda Shehaj}

Institute of European Studies, University of Tirana ermelindashehaj@yahoo.com

\author{
Doi:10.5901/ajis.2016.v5n3s1p188
}

\begin{abstract}
European Union from decades has been facing a struggle regarding the enlargement process and many question marks have been raised if enlargement would be beneficial for the Union itself and potential candidates that come from Eastern, south eastern and central Europe. Albania is one of the states, part of this process and a set of requirements have been given to Albania to fulfill and be qualified for the next step. Albania itself due to a non-well administration of post-communism from its political parties and leaders is still facing obstacles to integration. Therefore, one of the main obstacles that I will raise as an issue in this paper, part of my PhD research is a comparative analysis on the matter of property between Albania and other countries, specifically Romania, the Czech Republic and Poland. Countries that have been under the same regime, suffered more or less similar consequences of expropriations, but in years have found the ways to solve it and have different economic developments. Albania has good practices to follow with similar precedents on property that can be helpful toward integration road, depending on the will of its leaders and decision makers. Transition is still present in Albania and political climate it is not stable regarding many issues and reforms that have to be undertaken. The road has been difficult due to many factors, but what is important to emphasize is the fact that challenges help to improve, therefore Albania with international assistance and most important with its own will and political determinacy, must be on the right track to European Union.
\end{abstract}

Keywords: European Union, compensation, property rights, restitution, comparative

"Private property was the original source of freedom. It still is its main bulwark".

Walter Lippmann

\section{Introduction}

The issue of property rights in Albania started after the withdrawal of German army from Albanian territories. There were different types of property seizure, but according the Constitution of the Socialist Popular Republic of Albania private property does not exist, so the state become the legitimate owner of the seized land. After the '90s the rules acknowledged that the right to have private property is a fundamental human right. Also, the Constitution of 1998 legitimates private property. Many laws since the 90's have tried to make restitution or compensation, but the overlapping laws and procedures made the restitution and compensation complex.

Romania as well, is part of the same philosophy where communist regime and its Constitution of '48 expropriated industrial property, residential property and agriculture lands. Romanian framework for restitution and compensation has its own challenges but has found mechanisms how to solve the majority of the issue.

The case of the Czech Republic is very interesting to be studied, specifically the right of property. The Czech Republic is a country which has experienced a three-dimensional transition, apart from overcoming the socialist regime to a market economy, was faced also with a regional economy toward national economy and EU membership as an independent state.

Even though Poland has a communist past, shares more values as: political values, economic values and social ones with countries of Western Europe. However, even Poland which is affiliated more with Western couldn't escape the 
consequences of communism since it still deals with issues of property rights. In transition the economy is nor centralized (socialist) either capitalist (genuine democratic).

\section{Literature Review}

Privatization process in post-communist countries it is a very complex and complicated process. Privatization came as a result of the failure of communist. To overcome economic crises, the economy had to change from state (centralized) economy to market economy (laisse faire) to fulfill the society requirements. Privatization was obligation of states to make arrangements through a legal process, where state property would get transformed to private property, to be more productive and competitive for the new democratic regime. (Gordon: 1993). It has been very hard to find solutions to the privatization process. There hasn't been a unique model to apply, but each country has applied and adopted a model that would feet to their own the economic, legal and social circumstances.

As land privatization models have been used: shares giving to employs of the venture, distribution of shares to the people, selling of shares to investors and return of the property to prior landowners, land that was taken by force from the communist regime without compensating them. (Bennet: 2004) As mentioned above, depending on the specifications of the country, comes into implementation also the model of privatization, but to achieve bigger success each case has to have a clear legal framework, social consensus, good political will, transparency.

\section{Methodology}

This scientific work is based mainly on a comparative analysis between Albania and other Balkan Countries. Trying to bring a clear description of the similarities and contrast in hoping to extract thoughts to contribute in my best toward minor solutions or paths for solutions to the property rights issue which has become a burden to integration and to citizens itself. Each country has its own specifications although come from a similar regime. Analyzing mainly the challenges of each country (Albania, Romania, the Czech Republic and Poland) regarding property and how each of them tried to find ways to solve the issue is very interesting, because even though more or less the same past, the interest to solve the issue holds different priorities in each country. The priorities are related to economic capacities, political determination, social cohesion and most of all the democratic spirit the systems have.

\section{Analysis Content}

\subsection{Albania}

Albania belongs to states with a history of communist totalitarianism, where private property is liquidated and where the property belongs to the state. The state is the sole owner and employer.

In 1991 the newly elected parliament renewal of private property and reactivated the register of immovable property. Particularly important was the land law of 1991 under which agricultural lands were divided among those working and their families (about two-thirds of the population, in total). All former cooperatives were distributed as part of this process, although the details of implementation varied from province to province. (De Waal: 2005)

With the advent of democracy, the transformation of the economy took place even more chaotic than the political system. Through this law, the Albanian state creates a violation of human rights, depriving the legitimate owner from his property.

Albanian Constitution of 1998 in Art. 41- The right of private property is guaranteed. Art 42- The freedom, property and rights recognized by the Constitution and by law may not be infringed without a fair legal process. Then, laws as 7501, of 1991, "On land", agricultural lands were divided among those who worked on them, law 7652, of 1992, "On privatization of public housing," housing ownership passed to people who had them in use. Law 7698, of 1993, "On the restitution and compensation of property to former owners", provided a basis for further privatization in the city.

In 1993 they approved legal norms for property restitution and compensation. This law, made possible further privatizations. For agricultural areas came the principle "compensation instead of return". Then other laws give the possibility for legalization of informal areas, and create opportunities for continued occupancy of land illegally. Ineffective implementation law forced more and more population to question the authority of the state and law.

Land nationalized during the communist government, was not distributed on the basis of state law as in the south and north. In the south the implementation of land reform undertaken by the coalition government of 1991, as happened in Dropull didn't take into account any previous ownership.

Law no. 9404, dated 29.10.2004 "On the legalization and urbanization of informal areas", trying to regularize illegal 
buildings, according to a declaration process managed by the local government!

Law no. 9482, of 2006, "On the legalization, urbanization and integration of illegal constructions, replaces the law of 2004 and seeks to regularize illegal dwellings and buildings built before May 2006, subject to a declaration process managed by (ALUIZNI). (European Commmission:2003)

In Albania politics have used this issue in their favor. That's why even the legal framework has changed in continuity, trying to please individuals to gain more electorate and the changing of staffs every time new government would come in place made confusion, inefficiency and delay of the process. (Frangakis: 2008)

\subsection{Romania}

In Romania the law for land restitution was approved in 1991. Through this law came possible liquidation of collective farms, returning their lands that were taken from the communism to almost 3.700 families. With the reform more than 10 hectare were distributed to families but this specific law didn't manage the distribution of the $30 \%$ of the agricultural land. In '97 a new restitution of land was distributed, approximately 50 hectare workable land 30 hectare of agricultural land. Distribution of land came into life as a necessity. ). (European Commission: 1999)

According to this law, land has to be given back to the legitimate owners when it is possible, in the case where compensation in land was not possible, there should be a financial compensation. Distribution of land must be registered and accompanied with documents that verify the ownership of the land. In Romania over 800.000 hectare of exagricultural lands continues to be on states ownership. Land that was transformed into state land during world wars, as reclamation land and nobody had the right to inherit them by law. (Constantin: 2005)

Also, the Romanian Constitution prohibits by law foreigners to have rights of owning land. Legislation on foreign investments allows foreign companies to buy land for business, but only through a Romanian juridical person. Land market in Romania has started to work properly only after 1998, but is penalized by very high notarial tariffs and the right to pre-emption, where co-owners and neighbors or the tenant of the agricultural land has the right to buy it first if the land is put in the market to be sold. Romania has as strategy to prevent banks to own agricultural land and become big land owners that can bring land speculations. Therefore, law of 1998 prevents banks from being owners of land, lands gained as a result of bank executing requests.

Administrative programs of government regarding land, programs designed also according requirements of EU for membership is as follow:

1. Land registration: In order to be member of EU, as a condition Romania through landowners had to register the land. Due to historic events, Romania has been divided between Austro Hungarian and Ottoman Empire, therefore still suffers the lack of a unified registration system. At the moment are into force two different registration systems, "the book of land" and "inscription -transcription". Law of 1996 of cadaster for real estate is the fundamental legal act that adjusts land registration. A law that gives the right to the use of the book land. The book of land in the other hand has as a flaw the fact of the inability of gathering information in the offices of land book, therefore the information relies on local units of national cadastral offices. There is no security on the book of land, since in the law is not excluded the abolition of the land of book by court decision. So, people interested on land can't rely on the book of land because registration rights can be broken down and there is no certainty in the process.

2. Consolidating programs: Very small and not in the same location properties hinder the achievement of an EU level of living. (Cartwright: 2000) In Romania farmers have almost 2-3 hectare of land, 50\% of which is uncultivated due to the bad quality of the earth. Farmers have found solution to overcome this problem, only by creating family farmers associations, which creates more security and grow investments.

3. Plan and use of land: Many countries are dealing with policies of making government part of converting agricultural lands into nonagricultural use. Agricultural land in Romania is given to owners only when they are able to work on it and have knowledge on how to cultivate it. To convert the land is very expensive, but there is the option to do so.

4. Cohesive politics and land administration: Land administration has got two levels, the national and the local level. Until 2001 Romania didn't apply the law of restitution of property for urban buildings. Similar to Albania, after the fall of the regime of Nicolae Ceaușescu, laws on restitution of land taken during world wars and communism were in contradiction and created a massive confusion. In 2001 came into force law nr.10 "restitution of private property", restitution of property for the period of 19451989 (Decision 1/28 September 1998)

Timing was short for the complainant to apply for the property. Notification system was not functional, in this way 
many people living abroad would not catch in time the information. The government decided that citizens that have "sold the property" to the government during the communism for immigration reasons would not be compensated. In 2005 the government approved law No. 247, to improve the process of return of property, in the same time this law had as a goal to improve and simplify procedures, new deadlines for applications for return of property and imposing fines for whoever would infringe the process. Through this law the government achieved to eliminate some of the shortcomings of the previous legal framework for the return of the property, allowing the return of land in which a building was on construction through compensation, a procedure that in the previous law was not foreseen.

Law No. 247 of 2005 was a law that changed most of the frame work for the return of property, one of them eliminating deadlines on documents submission once and forever which support the complainant's allegations regarding ownership by allowing the plaintiff submitting new documents obtained and ownership certificate until the case is resolved. There was created a fund of E4 billion, which would be used to compensate former landlords, the property of which could not be returned. (Luca: World Bank 2005) Payments for property that cannot be returned will be given in the form of shares in an investment fund composed of 114 companies where, $97 \%$ of the stock is owned by the state.

\subsection{The Czech Republic}

The Czech Republic launched a structural and institutional reform, privatization of state enterprises, reform of the enterprise sector, financial sector, pensions and tax system reform, similar to Albania.

The Czech Republic chose the course of a gradual transition, while Albania followed shock therapy. From a planned economy to a market economy, the Czech Republic made a transition from regional to national economy, experience different from Albania

The Czech Republic inherited an ownership structure of the enterprises that was special because was based on self-rule, while Albania entered into transition with a structure dominated by state ownership. Countries like Albania were accompanied by drastic economic consequences, decrease of the overall product, social instability and rising unemployment.

The Czech Republic had the highest rate of growth among EU candidate countries, also positive social and political developments. Gradual policy has proved effectivity and efficiency for the Czech Republic.

The issue of compensation of property is a sensitive and complex issue. As well as in other post-communist countries that have passed or are still in transition, the issue is among the most frequent issues where politics gets involved for own benefits.

It is worth emphasizing that the European Court of Human Rights in a decision dated July 8, 1986, case X, held that Article 1 of Protocol No. 1 does not guarantee a right to full compensation in all circumstances, while legitimate targets such as "public interest", economic reform or social justice, can justify a compensation with a value of less than market value.

\subsection{Poland}

In Poland is a different situation, where the right of property ownership complies with the rule of law. Poland is the only country in post-communist block that does not have a law that provides return or restitution of private property. The legislation does not quote any provision for return or compensation. The only way to ask for a lost property is by individual request to the court, where in most cases limited compensation is offered.

In 2011, a statement of the Prime Minister clarified the situation of the Polish state due to economic difficulties, the compensation of property unfairly seized; even the minimum compensation from the state is unaffordable.

In early 1990s, property restitution and compensation has been an issue. With the establishment of the democratic system, Poland has undertaken measures in favor of the former owners. According to the legal framework, the seized properties must be returned to the former owners and a broad majority voted in favor, although the financial burden was too high.

Real reforms have made possible to pass to privatization and economic liberalization. The regime change brought changes in land ownership. International standards for human rights affecting property rights. Article 1, Protocol 1 of the European Convention provides the right to peaceful enjoyment of possessions and prohibits deprivation of possession unless they are in the general interest. In addition, any other deprivation of property is self-extinction of legal rights of the owner. 


\section{Conclusions}

All countries come from a communist regime. None of the laws at first was addressed at former owners. There was lack of political vision and frequent changes of the legal framework. Also, there was lack of administrative bodies and bureaucracy of the process.

In Albania international law on human rights takes precedence over national legislation, missing documents /human resources not available to speed up the process, the change of political power affects the institutional bodies to ensure property restitution, there does not exist a property fund for compensation, partial fund from the state is accorded

Romania differently from Albania has a higher capacity to pay for compensation, Romania as well beside distribution in kind, made compensation in cash and with shares, Romania didn't compensate former owners that left the country during communism and sold the land to the government, eliminated deadlines for documentation to claim property.

Czech Republic is the country that mostly had a European influence and that passed a gradual transition, which basically helped to solve many issues in a positive way for the country and its citizens. European Court of Human Rights decision does not cover and guaranties restitution in kind or compensation at all circumstances, meaning that compensation it's limited due to circumstances and can even be less than the market value.

In the meantime, Poland does not have a law that provides restitution in kind or compensation, but each person has to make individual request or complaint if has pretense to property. As an over all, beside the lack of funds for restitution Poland is allied with the former owners and European convention that protect property rights.

\section{References}

Allen, T. (1999) European Convention on Human Rights: University of Durham, UK

Bardhoshi, N. (2007) E drejta kanunore dhe shteti i së drejtës (The canonical rights and the rule of law): UET Press, Tiranë

Bianku, L. (2000) Të drejtat e njeriut në Europë. Botim i qëndrës Europiane (Human rights in Europe. European edition center)

Canaj, E. (2010) Respektimi i të drejtave dhe lirive themelore të njeriut në Shqipëri si kriter integrimi (Respect for human rights and fundamental freedoms in Albania as integration criteria's) Jus\&Justicia, Tiranë

Constantin, F. (2005) Privatization of Agriculture in some East-European Countries: Doctoral Thesis

De Waal, C. (2005) Albania Today: A portrait of Post-Communist Turbulence, I.B. Tauris.

Frangakis, N. (2008) Property restitution in Albania, briefing paper, Brussels

Gambeta, V (1999) Pronësia mbi tokën dhe historia e saj. (The ownership of land and its history): Mësonjtorja e parë, Tiranë

Mayer, L. (2003) Politikat krahasuese (Comparative politics) Tiranë: ORA.

Traja, K. (2001) Kushtetuta dhe sistemi i mbrojtjes të të drejtave të njeriut: (The Constitution and the system of protection of human rights: Soros, Tiranë

European Convention for the protection of human rights and freedoms

Universal declaration of human rights

European Commission progress reports (2009-2014)

World Bank: Report on property rights (European Convention for the protection of human rights and freedoms 009, 2011, and 2014)

Law no. 7501, (dated 19.07.1991) "On land"

Law no. 7698, (dated 15.4.1993) "On the restitution and compensation of property to former owners" 